\title{
FINANCIAL AND MARKETING PERSPECTIVE OF A COMPANY ACCORDING TO THE CONCEPT OF STRATEGIC BALANCE SCORECARD
}

\author{
Assoc. Prof. Jugoslav Aničić, PhD \\ "Union-Nikola Tesla University", Faculty of Entrepreneurial Business, Cara Dusana 62 -64, \\ 11000 Belgrade, Serbia, ajugoslav@yahoo.com \\ Vesna Petrović, PhD \\ Poenkareova 55 B, 35250 Paracin, Serbia, al.petrovicpn@gmail.com \\ Dušan Aničić, master \\ DSN Consalting, Zaplanjska 86 v, 11000 Belgrade, Serbia, \\ anicic.dusan@yahoo.com
}

\begin{abstract}
Summary: Balance scorecard was created in the 1990 's and it represents one of the most significant management ideas with the possibility of application in private, public and non-profit sector. It was created in need to respond to demands of intangible assets measurements which participate with more than a half of many great companies' value in last decades. Balance scorecard ensures insight into business possibilities and fulfillment of strategic goals from four perspectives: financial, marketing, internal and perspective of learning and growth. Balance scorecard measures and monitors human, information and organizational capital of a company with the aim of establishing to what extent this elements of intangible assets contribute to company's strategy realization. Standpoint for creation of this concept was an evident gap between corporate top strategy and understanding that strategy at lower levels of management and levels of translating strategies into actual business activities.
\end{abstract}

Key words: Balance Scorecard, intangible assets, financial perspective, strategy

\section{Introduction}

A large number of methods for measuring intangible assets by using financial and nonfinancial performance measures was created in the last decades. Scorecard models are among them, they are based on gaining data about elements of intangible assets that are presented as a list of results or in a form of a graphic depictions. These models can be applied relatively easy at any organizational level, and they represent the 'bottom-up' approach which enables numerous advantages as opposed to direct measuring methods or market capitalization models. Balances Scorecard concept emerged in 1990's in works by Kaplan and Norton and it represents one of the most significant managing ideas. Growing significance of intangible assets in the process of company's value creation had the greatest influence on this concept creation.

Balance Scorecard provides a wider insight into business possibilities and realization of strategic goals from different perspectives, covering financial, but also non-financial indicators of success. Concept is focused on mutual connection of different processes, decisions and results, from three time dimensional standpoints: 'yesterday', 'today', and 'tomorrow'. Starting point of Balance Scorecard concept is necessity of a contemporary company to be focused on strategy. Within a model, a range of different performance measures is used, through which a level of defined strategic goals is monitored. These goals are defined from four points of view: financial, marketing, internal processes perspective and learning and development perspective, respecting the principle that a strategy has to be in the center of planning decisions.

\section{Conceptual basis of Balanced Scorecard}

During last decades, a large number of methods for intangible assets measurement has developed, with the aid of financial and non-financial performance measurements. All those methods can be sorted into four larger groups and those are (Roos et 
all,2005): direct measurement methods, market capitalization methods, methods based on assets profit and scorecard models. First three groups have as a result financial value, while the last group is focused on non-financial measurements of intangible assets.

Scorecard models are based on gaining data about elements of intangible assets in order to present gained indicators in form of result list or in form of a graphic depiction. They can be applied relatively easily at any organizational level, and they represent the 'bottom-up' access which enables a more detail, accurate and faster depiction of this category of company's property than direct measurement methods or market capitalization models would provide. Scorecard models do not give a monetary intangible assets representation, so the main problem in their application is the inability to connect with financial business results. The most famous models from this group are Skandia navigator, List of chain value results, intangible assets monitoring and method of Balance Scorecard, with which we are going to deal with in this paper.

Balanced Scorecard was created in 1990's in works of Kaplan and Norton and it represents one of the most significant management ideas. A large number of worldwide companies uses Balanced Scorecard, both in private, public and nonprofit sector. A growing significance of intangible assets in the process of company's value creation process was what mostly induced creation of this concept. Balanced Scorecard provides a wider insight into business possibilities and realization of strategic goals from different perspectives, covering financial, but also non-financial indicators of success. Concept is focused on connections of different processes, decisions and results, from three time dimensional standpoints: 'yesterday', 'today' and 'tomorrow'. It is made for different hierarchical levels and business functions, it balances organization's external and internal constituents, on one, and late indicators and leading performances indicators, on the other side.

On the basis of analysis of 200 greatest companies in the USA, Kaplan and Norton identified a couple of conceptual restraints, which speak about non-existence of connection between long-term goals and strategy, on one side, and short-term goals and activities for their realization, on the other side. Precisely, those are: a) unclear vision, b) discrepancy between long-term goals and compensation systems, c) unsuitable resources allocation, d) tactic character of returnable information (Kaplan, Norton, 2004).

Authors have reached a conclusion that it is impossible to manage a structure on the basis of access and tools that are formulated for tactics operations management. That is why it was necessary to introduce an approach that has ambition to put a strategy in the hotspot of management processes and tends to connect goals with the strategy, as well as to connect formulation of a strategy with its implementation.

Balanced Scorecard concept has an idea to integrate different business aspects into one system of performances measurement, and the basis of the concept is a standpoint that a company cannot be properly managed solely by financial indicators. It is necessary to include measures that depict future performances and properly evaluate intangible assets influence in the process of value creation.

Conventional financial performances measurements are typical late indicators because they point to the results realized in the past. On the other hand, indicators such as market participation, sales rate and employees' satisfaction are measures of late performances. Leading indicators are initiators of future performances that cause creation of late indicators. They point to the possibility of value creation through different kinds of investments, above all, into different intangible assets. Time spent 
on collaboration with customers, investing into gaining new knowledge and skills represent typical leading performance measurements. According to that, companies that want to enhance their intangible assets management, have to integrate intangible assets measurements into their management system. Leading indicators and future performances measurements based according to them need to be balanced with the late indicators and success measurements that are results of the previous actions.

Conceptual basis of Balanced Scorecard is represented by answers on this four questions:

- How do we treat owners (financial perspective)?

- How do customers see us (customers' perspective)?

- How do we manage processes in order to reach excellence? (internal business operations' perspective)?

- How to enable qualification for changes and promotions (learning and growth perspective)?

Balanced Scorecard concept measures and monitors human, information, and organizational capital of a company, with the aim of evaluating to what extent mentioned elements of intangible assets contribute to the strategy realization. One of the deficiencies of this concept is emphasized through the fact that the employees are not analyzed separately from other categories of intangible assets, but they are seen as a joint part of learning and growth perspective, along with the company's information systems. Innovation, created as a result of human action is observed as a part of organization's internal processes perspective, i.e. as a routine business process in company that cannot be done without people. Consequently, activity of people and knowledge management was significantly underestimated within this concept. Also, application of Balanced Scorecard in intangible assets measurements does not enable comparison to other companies, because its basic intention is to be used internally, for the needs of company's management.

Within Balanced Scorecard, intangible assets effect can be seen through following causal connections:

1. Investments into staff straining lead to the quality of products and company's services enhancement

2. Higher quality of products and services leads to a clients' higher satisfaction

3. Clients' higher satisfaction has an impact on increasing clients' loyalty

4. Increase in clients' loyalty generates profit growth and company's gain

Tangible results of strategy are described by financial perspective through traditional accounting indicators relating to income, profitability, and assets' employment. By their nature, these conventional financial performance measurements do not communicate with future performances initiators. The most frequently used indicators in this perspective are profitability, liquidity, assets' application efficacy and market capitalization.

Relying solely on accounting indicators promotes a short-term orientation that leads to sacrificing long-term value for the shortterm profit. Balanced Scorecard, along with the previous indicators measurements, also applies initiators or leading indicators of future performances (Djuricin, Janosevic, 2007). The basic idea is that every measurement of performances represents part of causal connection chain. Observing goals from different perspectives, Balanced Scorecard makes a balance between general performances measurements (financial conventional past decisions) and initiators of performances (measurements of future performances that talk about ways of value creation through investments into consumers, providers, employees, technology, innovations and other kinds of intangible assets). 
Company's management applies system of parameters in order to change reached results, compare them to the set goals and on that basis manage the company in a complex economic environment. Financial parameters such as ROE (Return on Equity), ROCE (Return on Capital Employed), DuPont, ZVEI (Zentralverband der ElektrotechnischenIndustrie) etc. are used therein. Main deficiency of these parameters is that they are based solely on financial data from the past years, while the factors concerning future are not included in reports of company's business operating. In order for company management, that is based on long-term goals, to be successful, parameters must contain indicators that not only reflect past but also provide the information on the future growth.

Offer value for certain buyers is defined by buyer's perspective, and three most important value dimensions are product/services features, connection to buyers, and business image. Market participation, introducing new products, customers' satisfaction and loyalty represent the most important goals that are to be provided. Measurements usually used in order to achieve these goals are: size of market participation, participation of new products in overall income, number of customers, sales per customer, etc.

\section{Application of Balanced Scorecard}

Starting point of Balanced Scorecard is necessity for a contemporary company to be focused on a strategy. Therefore, Balanced Scorecard places strategy in the center of management process. Principles on which a company led by strategy is based on are: a) continuous preoccupation and maximum participation of employees; b) translating strategy to operational/tactical decisions; c) integration in function of synergy; and d) leadership in changes (Djuricin, Janosevic, 2007).

A range of different performance measurements through which a level of achievement of defined strategic goal is monitored, is applied within a model. These goals are defined from four perspectives (financial, marketing, internal processes perspective, and learning and growth perspective), with respect to the principle that a strategy need be in the center of planning decisions.

Basic standpoint for creation of the Balanced Scorecard was an evident gap between the strategy defined at the organization's strategic top and understanding the strategy by managers at the lower levels and by immediate executors that are to translate the strategy to tactical decisions and specific business activities. The solution was found in the act of translating strategy into a group of precisely defined goals understandable to managers and employees at any organizational level. Next step was defining appropriate measurements by which level of strategic goals realization would be monitored. Finally, implementation of strategy described by goals, performance measurements and assignments, requires offering a framework to all relevant decision makers that would enable automatic implementation of appropriate activities. That is achieved by adding strategic initiatives (or action plan) that show what is necessary to be done in order to fulfill assignment and achieve goal, to the defined goal that is specified through assignments and whose achievement is monitored through performance measurement.

Balanced Scorecard also represents tools for formulation and implementation of a strategy. From existing to desirable state, it is necessary to perceive numerous causal connections, before all, relating to the activities (leading indicators) and desirable outcomes (late indicators). These relations have to be explicitly perceived in the process of formulation and implementation of a strategy. It is necessary for them to satisfy condition in terms of the possibility of testing and adaption to the changed 
conditions of contemporary knowledge society.

Example of Balanced Scorecard is shown in the Table 1.

\begin{tabular}{|c|c|c|c|c|}
\hline & Objectives & Measurements & Assignments & Initiatives \\
\hline & $\begin{array}{l}\text { What is desired } \\
\text { with } \\
\text { The strategy? }\end{array}$ & $\begin{array}{l}\text { How to monitor goal } \\
\text { fulfillment }\end{array}$ & $\begin{array}{c}\text { Desirable performances } \\
\text { or enhancement rate }\end{array}$ & Key moves \\
\hline $\begin{array}{l}\text { Financial } \\
\text { perspective }\end{array}$ & $\begin{array}{l}\text { - Profitability } \\
\text { - Liquidity } \\
\text { - Capitalization }\end{array}$ & $\begin{array}{l}\cdot \text { EBITDA } \\
\cdot \text { Cash flow } \\
\cdot \text { EPS }\end{array}$ & $\begin{array}{l}\cdot \cdot 3.2 \mathrm{~m} € \\
\cdot 2.2 \mathrm{~m} €(5 \%) \\
\cdot 7 \mathrm{~m} €(10 \%)\end{array}$ & $\begin{array}{l}\text { - Investments } 6 \mathrm{~m} € \\
\text { - Termination of } \\
\text { Sales lending } \\
\text { - Corporative } \\
\text { management }\end{array}$ \\
\hline $\begin{array}{l}\text { Marketing } \\
\text { Perspective }\end{array}$ & $\begin{array}{l}\cdot \text { Market } \\
\text { participation } \\
\text { - Loyalty } \\
\text { - Marketing } \\
\text { intensity } \\
\end{array}$ & $\begin{array}{l}\text { - Relative market } \\
\text { participation } \\
\text { - Rental rate } \\
\text { - Percent of market } \\
\text { sales } \\
\end{array}$ & $\begin{array}{l}\cdot 1.5 \\
\cdot 80 \% \\
\cdot 10 \%\end{array}$ & $\begin{array}{l}\text { - Differentiating } \\
\text { - E-market } \\
\text { - Strategic plan }\end{array}$ \\
\hline $\begin{array}{l}\text { Process } \\
\text { perspective }\end{array}$ & $\begin{array}{l}\text { - Automation } \\
\text { • ERP }\end{array}$ & $\begin{array}{l}\text { - } \% \text { automated } \\
\text { processes } \\
\text { - Number of licenses }\end{array}$ & $\begin{array}{l}\cdot 70 \% \\
\cdot 10,5,4\end{array}$ & $\begin{array}{l}\text { - Strategic } \\
\text { adaptation } \\
\text { - Competence center }\end{array}$ \\
\hline $\begin{array}{l}\begin{array}{l}\text { Learning } \\
\text { and growth }\end{array} \\
\text { perspective }\end{array}$ & $\begin{array}{l}\text { - Strategic } \\
\text { skills } \\
\text { - Manager } \\
\text { team stability } \\
\text { - Training }\end{array}$ & $\begin{array}{l}\text { - ERP, BSC, Excel } \\
\text { - Manager's } \\
\text { Retention rate } \\
\text { - Number of training } \\
\text { days }\end{array}$ & $\begin{array}{l}\text { - Operative and } \\
\text { Tactical level } \\
\text { - } 90 \%\end{array}$ & $\begin{array}{l}\text { - School } \\
\text { Of management } \\
\text { • Bonus plans } \\
\text { - Condition } \\
\text { For advancement }\end{array}$ \\
\hline
\end{tabular}

Source: Djuričin, D., Janošević, S., Kaličanin, Dj: (2013) Management and strategy, CID, University of Belgrade, Faculty of Economics, p. 94.

Application of Balanced Scorecard enables connection and dynamics of formulation and strategy implementation phases, and in this manner these phases become two sides of the same coin. Because of the contemporary business conditions' characteristics, the ability of strategy application has become much more important than ability of its formulation. Among qualities of the most successful companies is the ability to carry strategy into effect fast, or to implement a formulated strategy. Problem occurs if the phases of strategy formulation and implementation are separated, complicating its application, because strategy realization represents a processes that includes, above all, creation of suitable organizational structure and business culture, and using resources whose usage should be planned and controlled.

Some authors criticize Balanced Scorecard, starting by that that a chain of causal connections described, does not contain a time dimension of lateness between cause and a consequence (Norreklit, 2000). Dror (2008) sees as a concept's deficiency the basis directives' non-existence for selection 
of performance measurements, and thatthe feedback from financial perspective towards customers' perspective and internal business processes is very complex. Kanji and Maura (2001) emphasize that the Balanced Scorecard's deficiency is in the very model's conceptuality, because it cannot be easily translated into a measurement model, and also that a model is not dynamic enough in terms of monitoring the competition and technological development.

Besides mentioned deficiencies, one of the key lacks of a model is a fact that Balanced Scorecard is a rigid method. Rigidity comes from leading managers to identify critical factors of success from the identified perspective of Balanced Scorecard, within the mentioned perspectives. This appears restraining due to the fact that many critical factors of success are common for more perspectives, and cannot be assigned to only one of them. Therefore, managers can predict some significant factors of success that do not categorically belong to one of the perspectives. Besides this, Balanced Scorecard rigidity (Bontis et all, 1999) comes from the fact that external environment with clients is tacitly equalized within a model, without concerning providers, alliance partners, local communities or syndicates. Balanced Scorecard is developed on the basis of experiences with great economic companies, and consequently, it rarely takes into account considering and analysis of the factors that play an important roles within small and middle-sized enterprises' sectors.

\section{Conclusion}

Management operates a company in a complex economic environment according to the parameters used for measuring realized results in comparison to the set goals. In the course of that, financial parameters, such as ROE (Return on Equity), ROCE (Return on Capital Employed), DuPont, ZVEI (Zentralverband der ElektrotechnischenIndustrie), etc. are used. The main deficiency of these parameters is that they are based solely on financial data from the previous years, while factors that have an impact on company's future are not included in reports on company's business operating. In order for company's management to be successful, according to the long-term goals, parameters must include indicators that not only reflect on past but they also provide information on future company growth.

Balanced Scorecard measures and monitors human, information and organizational company capital, with the aim of evaluating to what extent mentioned elements of intangible assets contribute to the strategy realization. Standpoint of Balanced Scorecard is necessity of contemporary company to be focused on strategy. Principles on which strategy-led organization is based on, are continuous preoccupation and maximum participation of the employees, translating strategy into operating decisions, integration in synergy function, and leadership in changes. Balanced Scorecard provides phase formulation and strategy implementation link and dynamics, and the most successful companies have the ability to put strategy into effect fast, or to implement a formulated strategy. Among deficiencies of this concept, it is emphasized that it was created according to the great economic companies' experiences, and, therefore, has a restraining application in small and middle-sized enterprises' sectors.

\section{Literature}

Bontis, N., Dragonetti, N. C., Jacobsen, K., Roos, G. (1999): The knowledge toolbox - a review of the tools available to measure and manage intangible resources, European Journal of Management, Vol. 17 , No. 4 , p. $391-402$

Dror, S., (2008): The balanced scorecard versus quality award models as strategic frameworks, Total Quality Management, Vol. 19, No.6, p. 583-593.

Djuričin, D., Janošević, S., (2007) Management and strategy, CID, University of Belgrade, Faculty of Economics 
(JPMNT) Journal of Process Management - New Technologies, International

Vol. 4, No.1, 2016

Djuričin, D., Janošević, S., (2007)Management and strategy, CID, University of Belgrade, Faculty of Economics,Beograd, p. 583

Janošević, S, Dženopoljac, V., (2013) The Balanced Scorecard vs. Total Quality Management, TTEMtechnics Technologies Education Management, Vol. 8, No.1, p. 373-383.

Kaplan, R. Norton, D. (2004): Strategy Maps Converting Intangible Assets into Tangible Outcomes, Harvard Business School Press, Boston, Massachusetts
Kaplan, R. and Norton, D. (1996): The balanced scorecard - translating strategy into action, Harvard Business School Press, Boston, p. 9

Kanji, G.P., Moura, E. Sa. P., (2001): Kanji s business scorecard, Total Quality Management, Vol. 12, No.7, p. 898-905.

Norreklit, H., (2000): The balance on the balanced scorecard - a critical analysis of some of its assumptions, Management Accounting research, Vol. 11, No.1, p. 65-88.

Roos, G., Pike, S., Fernstrom, L., (2005): Managing Intellectual Capital in Practice, ButterworthHeinemann, Oxford, p. 247-255 